\title{
Formação e transformação: \\ para além do capital
}

Caio Sgarbi Antunes

Mestrando em Educação (Unicamp/Paideia)

\section{Mészáros, István. A educação para além do capital. São Paulo, Boitempo, 2008.}

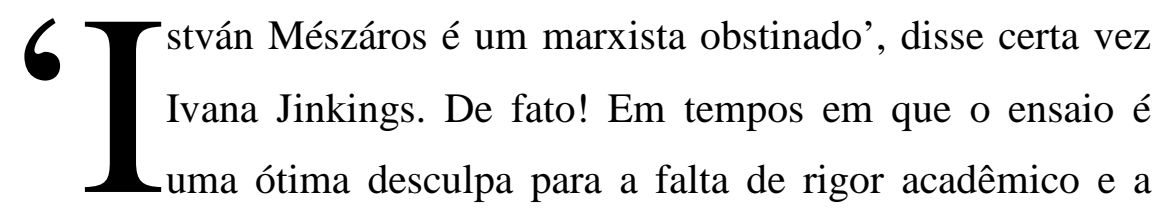
ausência de critério científico, István Mészáros nos brinda com A Educação para Além do Capital.

Preparado originalmente para a conferência de abertura do Fórum Mundial de Educação (Porto Alegre, 2004), este magistral ensaio, que impressiona pelo fôlego e densidade e que muito rapidamente tornou-se um clássico do pensamento educacional emancipatório, vem agora a público (após duas reimpressões) em segunda edição, contendo como anexo o texto Educação: o desenvolvimento contínuo da consciência socialista.

O ponto de partida necessário para a compreensão do conceito de educação em Mészáros (na esteira de Marx e Lukács ${ }^{1}$ ) é sua apreensão em sentido amplo, como 'a própria vida'2. Uma tal ampliação conceitual articula ainda mais profundamente a educação à totalidade dos processos sociais de produção e reprodução da vida.

Sob o capital, a educação tem o sentido de internalização dos parâmetros reprodutivos gerais do sistema, não devendo ser compreendida como restrita ao que ocorre em uma instituição formal de ensino. É fato que as 'instituições formais de educação certamente são uma parte importante

\footnotetext{
1 Isto fica evidente se tomarmos as concepções de educação expressas por Marx desde seus Manuscritos Econômico-Filosóficos (especialmente o capítulo Propriedade Privada e Trabalho) e por Lukács em sua Ontologia do Ser Social (especialmente o capítulo sobre $A$ Reprodução).

2 Conforme a epígrafe utilizada por Mészáros para abrir o livro: 'A aprendizagem é a nossa própria vida, desde a juventude até a velhice, de fato quase até a morte; ninguém passa dez horas sem nada aprender' (Paracelso).
} 
do sistema global de internalização', mas elas são dele 'apenas uma parte'. Deste modo, embora o período de educação institucionalizada seja limitado sob o capitalismo a relativamente poucos anos de vida dos indivíduos, a dominação ideológica da sociedade prevalece por toda a sua vida. Os processos de 'internalização' ideológica cumprem, deste modo, a dupla função de, por um lado, criar qualificações necessárias ao funcionamento da economia e, por outro, elaborar métodos de controle político.

Em obscuros tempos reformistas, Mészáros nos mostra que 'reforma sistêmica na própria estrutura do sistema do capital é uma contradição em termos'. Não se trata da minimização dos impactos desumanizadores do 'espírito comercial'; a questão central é a impossibilidade ontológica de plena realização humana sob os ditames do sistema de metabolismo social do capital. Portanto, 'limitar uma mudança educacional radical às margens corretivas interesseiras do capital significa abandonar de uma só vez, conscientemente ou não, o objetivo de uma transformação social qualitativa'.

Mesmo as preocupações humanitárias genuínas presentes nas utopias educacionais mais nobres da tradição iluminista liberal (que somente poderiam surgir na fase ascendente das transformações capitalistas), por mais precisas que pudessem ser na identificação dos 'excessos e impactos da nova ordem emergente', estavam fadadas ao fracasso. Toda a precisão na identificação destes 'excessos e impactos' teve de ceder lugar a uma generalização de 'erro e ignorância' como razão fundamental dos fenômenos denunciados, a serem corrigidos pelo bom uso da 'razão e do esclarecimento'. Por se identificarem com o ponto de vista do capital, tais utopias não puderam - como não poderiam - perceber a incompatibilidade estrutural entre seus ideais educativos e a lógica desumanizante do capital.

Porém, o 'erro' do ponto de vista destas utopias não se corrige por meio do uso de 'razão e esclarecimento'. A diluição da tão precisa diagnose em soluções vagas e circulares deve-se ao fato de as soluções encontradas já estarem postas, predefinidas pela adoção do ponto de vista do capital; assim, o problema tem de ser redefinido ou alterado até se ajustar à solução. Não se trata de um problema teórico, mas sim prático. O equívoco da 'mudança 
resenha

significativa como perpetuação do existente' não é epistemológico, é ontológico!

Se cada âmbito particular da existência humana é profundamente afetado pelas determinações gerais da produção e reprodução da vida, um projeto educacional só pode efetivamente funcionar se estiver profundamente integrado à totalidade dos processos sociais. Deste modo, uma contestação à educação, por afetar diretamente os próprios processos de internalização ideológica, representa uma profunda contestação à estrutura social em questão.

É neste intrincado nível de articulação que 'nossa tarefa educacional é, simultaneamente, a tarefa de uma transformação social, ampla e emancipadora'. A luta pela educação coincide com a luta pela eliminação consciente da autoalienação do trabalho, pois, bem sabemos - desde as Teses sobre Feuerbach ${ }^{3}$ - que a 'educação não pode funcionar suspensa no ar'.

O preceito ontológico que orienta o processo consciente de 'uma mudança societária oniabrangente' é o trabalho como 'atividade humana auto-realizadora'. É o imperativo do tempo disponível para a humanidade o princípio orientador da produção e reprodução material e cultural da vida, em categórica oposição ao tempo de trabalho necessário para o capital. Mas isto sem jamais perder de vista que 'as tarefas imediatas e suas estruturas estratégicas globais não podem ser separadas ou opostas umas às outras'. 'O caminho que conduz à realização completa da igualdade substantiva deve ser tomado hoje'.

Portanto, a educação, entendida como 'desenvolvimento contínuo da consciência socialista', aponta para uma ordem sociometabólica radicalmente distinta que se sustente concretamente sobre si própria. A

\footnotetext{
3 Mais precisamente, a terceira tese (também utilizada por Mészáros como epígrafe do livro). 'A teoria materialista de que os homens são produto das circunstâncias e da educação e de que, portanto, homens modificados são produto de circunstâncias diferentes e de educação modificada, esquece que as circunstâncias são modificadas precisamente pelos homens e que o próprio educador precisa ser educado. Leva, pois, forçosamente, à divisão da sociedade em duas partes, uma das quais se sobrepõe à sociedade (...). A coincidência da modificação das circunstâncias e da atividade humana só pode ser apreendida e racionalmente compreendida como prática transformadora' (Marx).
} 
resenha

contraposição toma, radical e conscientemente, o lugar das correções remediadoras. É este o sentido concreto, ontológico, de 'formas de ser, determinações de existência', numa palavra, de categorias para além do capital.

Cabe ressaltar que os dois importantes e contundentes trabalhos (profundamente articulados entre si) que compõem esta segunda edição têm suas origens quase 40 anos atrás, mais precisamente após o mergulho profundo nos chamados Manuscritos de Paris e a partir da compreensão de ser a autoalienação do trabalho a 'raiz causal de todo o complexo de alienações'. Em seu livro A Teoria da Alienação em Marx ${ }^{4}$, István Mészáros analisa o complexo da alienação e suas variadas formas de manifestação na vida cotidiana do 'indivíduo social', desde seus aspectos econômicos e políticos até os estéticos e morais. Obviamente, a educação não poderia deixar de estar presente.

Contudo, o texto Educação: o desenvolvimento contínuo da consciência socialista traz a contribuição educacional de Mészáros para um plano não ainda atingido em seus escritos anteriores.

Afirma nosso 'obstinado filósofo' que uma 'transformação social qualitativa' só pode de fato ocorrer com a efetiva contribuição da educação, mas é a própria transformação, em seu 'ir sendo', que efetivamente contribui para a conformação, para a redefinição do processo educacional. Isto significa que somente por meio da transformação pela educação e da educação para a transformação ou, numa palavra, somente por meio da profunda reciprocidade entre formação e transformação, é que a igualdade substantiva pode passar de abstração a princípio orientador, e deste a realidade social. Obviamente, toda a magnitude destas transformações só pode ser assegura pela participação genuína nas decisões e no planejamento societário abrangente. Este é o sentido concreto dos 'indivíduos livremente associados' a que Marx tanto se referiu.

O vigoroso aprofundamento da dimensão propositiva aí contida remete a uma elaborada combinação do 'pessimismo da razão' ao ‘otimismo

${ }^{4}$ Originalmente publicado sob o título Marx's Theory of Alienation, em Londres, 1970. 
resenha

da vontade'. Bem sabemos que 'o poder material tem de ser derrubado pelo poder material, mas a teoria converte-se em força material quando penetra nas massas'. Porém, a 'teoria só se realiza num povo na medida em que é a realização de suas necessidades'. 